\title{
ANALYSIS AND CHARACTERISATION OF ADOBE BLOCKS IN JOJUTLA DE JUÁREZ, MÉXICO. SEISMIC VULNERABILITY AND LOSS OF THE EARTHEN ARCHITECTURE AFTER THE 2017 PUEBLA EARTHQUAKE
}

\author{
A. Sanchez-Calvillo ${ }^{1, *}$, D. Preciado-Villicaña ${ }^{2}$, E. G. Navarro- Mendoza ${ }^{1}$, E. M. Alonso-Guzman ${ }^{2}$, E. A. Nuñez-Guzman ${ }^{2}$, \\ H. L. Chavez-Garcia ${ }^{2}$, M. Ruiz-Mendoza ${ }^{2}$, W. Martinez-Molina ${ }^{2}$ \\ ${ }^{1}$ Programa Interinstitucional de Doctorado en Arquitectura, PIDA, Faculty of Architecture, Universidad Michoacana San Nicolás de \\ Hidalgo, Morelia, México - adria.sanchez.9@ hotmail.com, dnavarrom@gmail.com \\ ${ }^{2}$ Materials Department, Faculty of Civil Engineering, Universidad Michoacana San Nicolás de Hidalgo, Morelia, México - \\ (dpv23.110196, eliamercedesalonso, melissaruizmendoza.mrm, wilfridomartinezmolina)@ gmail.com, \\ (eralnu, hchaveznator)@hotmail.com,
}

Comission II - WG II/8

KEY WORDS: Earthen architecture, Seismic vulnerability, Seismic culture, Sieve analysis, Colorimetry

\begin{abstract}
:
The 2017 Puebla Earthquake on 19 September struck a big part of central Mexico causing the loss of historic buildings in several states, being the state of Morelos one of the most damaged in the whole country. Jojutla de Juarez was the most affected locality of Morelos presenting important structural damages or total collapse in the built heritage, being the traditional earthen buildings, made of adobe bricks, the most vulnerable buildings to seismic efforts. Some of the causes which contributed to the poor behaviour of the buildings were the improper handling of the constructive systems and materials, the insufficient resistance of the structures and the problems with the foundations. The adobe houses of Jojutla presented a mixture between the traditional building techniques and industrial materials like concrete, cement and steel; also with irregular heights and plant layouts and inadequate connections between the walls and foundations and roofs, resulting into a higher seismic vulnerability when the earthquake impacted. Also the adobe bricks presented irregularities in its composition and use of additives which resulted in completely different typologies and the loss of the traditional construction techniques. A study was conducted to determine the properties of the remains of the adobe bricks of the houses in Jojutla, considering that the structures were severely damaged and a whole study of the seismic vulnerability would not be convenient due the loss of the physical traditional buildings. The grain size and composition of the adobe samples of the buildings were determined as well as the natural aggregates like straw, sand, and its proportion. A colorimetric study of the adobes and clays was also conducted, analysing the change of colour on account of the aggregates in the bricks. Also the compressive strength of the pieces was tested with two methods: the compression test and the point-load test, in order to obtain the indicative values which could be compared to other patrimonial and vernacular study cases.
\end{abstract}

\section{INTRODUCTION}

\subsection{The seismic events of September 2017}

In the year 2017, Mexico was struck by two major earthquakes which had a big impact on the society and caused important damages in several states of the country. These two events occurred during the month of September and caused major material losses in the built heritage which is a fundamental part of the identity and culture of the society.

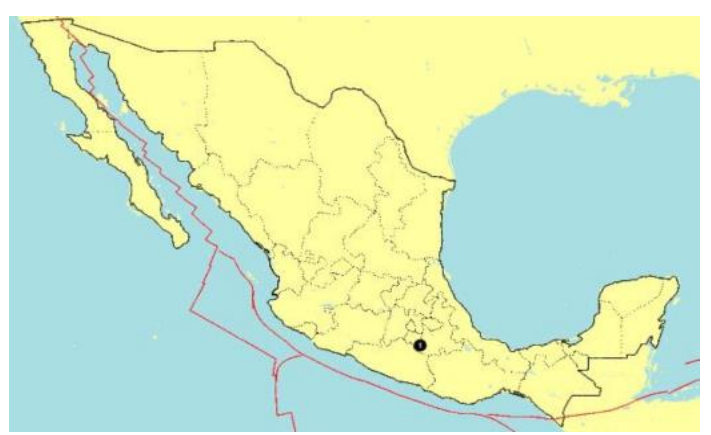

Figure 1. Epicentre of the 2017 Puebla earthquake.
Still today, the damages are visible in the affected regions, being the physical and material state of the monuments a remembrance of these natural disasters. The first earthquake struck on September 7th of 2017 in the Gulf of Tehuantepec, between the Mexican states of Oaxaca and Chiapas, with a magnitude of 8.2 being originated in the Cocos Plate. This natural disaster was marked by the multiple aftershocks which were detected on the following days, causing damages mainly in the states of Chiapas, Oaxaca and Tabasco (Servicio Sismológico Nacional, 2017).

On the other hand, the second earthquake occurred on September 19th with a magnitude of 7.1 and a detected epicentre on the boundaries between the states of Puebla and Morelos, located $12 \mathrm{Km}$ southeast Axochiapan, Morelos (Servicio Sismológico Nacional, 2017). In this case, the most affected states were Puebla, Mexico State, Morelos, Tlaxcala, Guerrero and Mexico City. As it can be seen in Figure 2, Jojutla was near to the epicentre of the earthquake, about approximately 50 kilometers, therefore it was inside the most severe seismic intensity region with values of peak ground acceleration between 130 and $150 \mathrm{~cm} / \mathrm{s}^{2}$ (Servicio Sismológico Nacional, 2017).

\footnotetext{
* Corresponding author
} 
These events had an enormous impact on the architecture and construction of the country, being the Puebla Earthquake especially destructive to the colonial buildings which are part of the Mexican cultural heritage produced by the arrival of the Spanish in the 15th Century. While Morelos was the fourth state with more damaged monuments after Puebla, Oaxaca and the State of Mexico respectively, the degree of damage was considerably greater. Morelos was the only state to have a bigger percentage of severe damages (including collapse of buildings) than medium or minor damages, representing the $47.10 \%$ of the total monumental buildings afflicted. Putting this fact into perspective, the following states with bigger percentages were Mexico City with $25.89 \%$ and Puebla with 25.89\% (Meli Piralla, 2018).

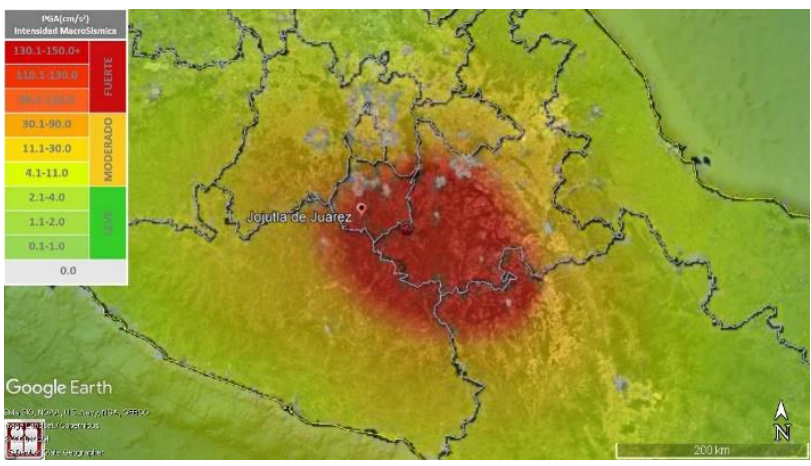

Figure 2. Seismic intensity of the 2017 Puebla Earthquake and location of Jojutla de Juárez. Source: Google Earth Pro / Servicio Sismológico Nacional.

Jojutla de Juárez was the most affected locality of the State of Morelos, presenting important structural damages or total collapse in the built heritage, being the traditional earthen buildings, made of adobe bricks, the most vulnerable buildings to seismic efforts. The historic centre of the town was widely damaged, suffering important losses in the built heritage, like the churches and main institutions, as well as the public housing. After the earthquake, México was on the scope of global concern, receiving humanitarian and material aid by many countries and non-governmental organizations. The impact in Jojutla de Juárez was immediate but also prolonged, many families had to live in rescue tents even a year after the catastrophe and the reconstruction of the town has lasted until today.

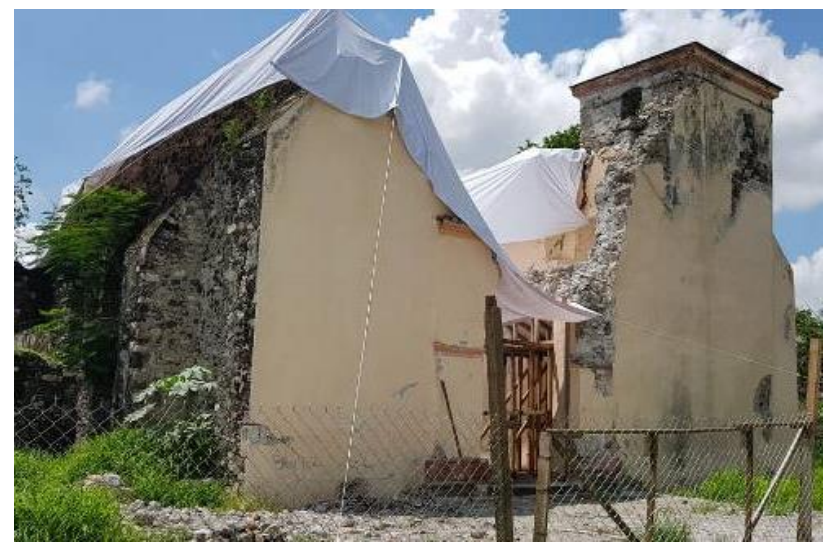

Figure 3. Colonial church damaged by the 2017 Puebla earthquake in Jojutla de Juárez, Morelos. Photo: Adrià Sánchez Calvillo (2018).

\subsection{The traditional adobe architecture in the State of Morelos}

The vernacular architecture of the State of Morelos has been studied as a particular typology since the 90 's, finding the first approaches from the perspective of architectural technology and construction like the research of Guerrero Baca (Guerrero, 1996), identifying the main characteristics of the traditional buildings and the adaptation to the local environment. One of the main properties of the traditional architecture is its cultural adaptation, intended as the integration and interaction that human beings establish in a territory (Niglio, 2015).

To recognize the local seismic culture of some regions it is necessary to identify seismic-resistant strategies in its structures and constructions, and also these strategies need to be replied intentionally, if not, they would be isolated cases, contrary to the main concept which is the 'typological solution' (Jorquera, 2014). During the last years, there has been a paradigm shift regarding seismic retrofitting and natural hazards studies; research is focusing on a solution which has a long-term historical perspective learning from the strategies developed by our ancestors (Ferrigni, 2015). In Mexico, as well as all American continent, the seismic strategies used nowadays in architecture and engineering are the result of an interaction between the preColumbian local constructions and materials and the new technologies broguht by the Europeans since the 16th century (Guerrero Baca, Vargas Neumann, 2015). This symbiotic relatinoship generated a very rich local seismic culture wich evolved through trial and error, producing the current vernacular architecture which many individuals and organisations are trying to recover.

Several of these strategies have been found in the adobe houses of the State of Morelos, with particular research done in the Valles Altos region near the Popocatepetl volcano (Guerrero Baca et al., 2014). The traditional buildings in this territory present simple rectangular architectural plans, stone foundations which prevent the water ascent by capillary action, adobe walls with considerable thickness and wooden roof systems which have a flexible behaviour regard dynamic efforts. After the 2017 Puebla earthquake, this local seismic culture responded reasonably well to the earthquakes, partly because of the simplicity of the constructions and the flexibility of the systems (Guerrero Baca, 2019).

On the other side, the early monasteries of the State of Morelos, which have an enormous importance for the cultural heritage of México, being a UNESCO World Heritage Site, presented severe damages (Díaz Fuentes et al., 2019). These monasteries, much heavier, higher and rigid, registered severe damages which challenged their functionality; however as they were categorized as monuments, they received huge interest by the organisations. While these historical constructions were thoroughly assessed, in constrast, the vernacular architecture was forgotten.

Nevertheless, while some of the vernacular and monumental architecture of the state of Morelos has remained till today, most of the current buildings and constructions have been altered or reconstructed. In particular, the earthen constructions have been underestimated by the population, considering it a symbol of poverty and cultural backwardness (Guerrero Baca, 2007) This condition can be spotted globally, with many analogous cases which have experienced similar damages after important earthquakes (Blondet et al., 2011; Sunkar, Aksoy, 2015). 


\subsection{Jojutla de Juarez and the scenario after the 2017 Puebla earthquake}

The study case of Jojutla de Juarez, had forgotten this local seismic culture and strategies derived from vernacular architecture. Instead, the traditional houses had incorporated new materials and elements which were not compatible and contributed to increase the seismic vulnerability of the buildings. Some of the deficiencies found in Jojutla which contributed to this vulnerability were: the incorrect location of the openings like doors and windows, the lack of horizontal reinforcements, walls with insufficient thickness, the bad quality of the adobes, the lack of diaphragm between the walls and the roof structure, the use of non-compatible materials or the irregularities in the morphology and height of the buildings among many others. All these factors have been identified in adobe architecture worldwide, and lead to the collapse of the earthen structures when earthquakes struck (Yamín Lacouture et al., 2007; Blondet et al., 2011).

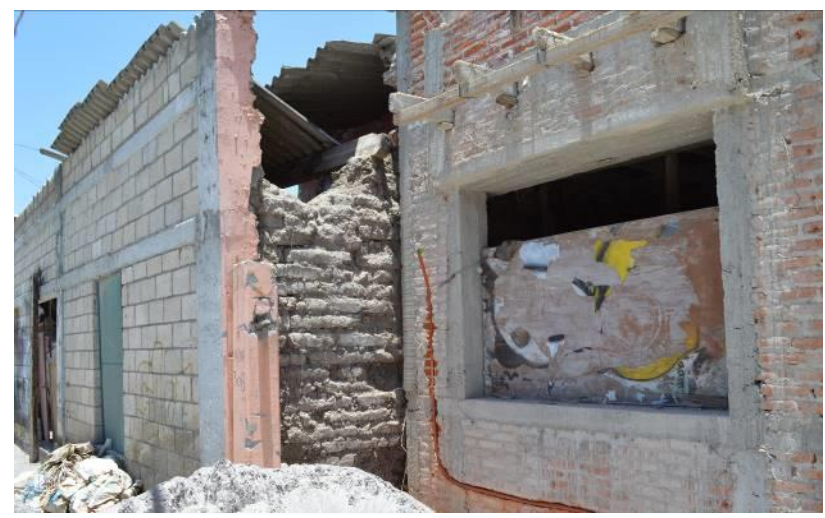

Figure 4. Adobe traditional dwelling with several modifications after the 2017 Puebla earthquake in Jojutla de Juárez, Morelos.

Photo: Adrià Sánchez Calvillo (2018).

(c) SPOT Image Copyright 2020.

Jojutla de Juarez showed a micro-seismic-regionalisation, especially in some of its colonies or neighbourhoods. The historic centre of the town was widely damaged, suffering important losses in the built heritage, like churches and main institutions, as well as the public housing. From the report of the Emergency Brigades the $39.80 \%$ of all buildings in Jojutla presented a high risk, which could mean danger of collapse, important structural damages or weak walls among others; $52.25 \%$ presented low risk with minor or reparable damages, and the $7.95 \%$ remaining presented an uncertain risk. The large majority of the adobe houses were located in the downtown colony, which was the most affected zone with the Emiliano Zapata colony, re-built more recently. Both zones experienced severe damages, including the collapse of many buildings and structures. The geotechnical study of the Emiliano Zapata colony concluded that there were three major reasons for the great seismic vulnerability shown: 1) Bad construction practices, 2) Insufficient resistance of the structural systems, 3) Issues with the foundations (del Campo Alatorre et al., 2018).

On the other hand, other of the major contributions to the great vulnerability of the town was the lack of risk management plans. The municipal development plan of the city council of Jojutla de Juárez, published on May of 2016, months before the seismic events, had not any mitigation strategies against natural phenomena. The document had 93 development agendas focused on different themes like economy, ecology, culture, education, etc. but none of these programs had to do with natural risks management and vulnerability (Consejería Jurídica del Poder Ejecutivo del Estado de Morelos, May 2016).

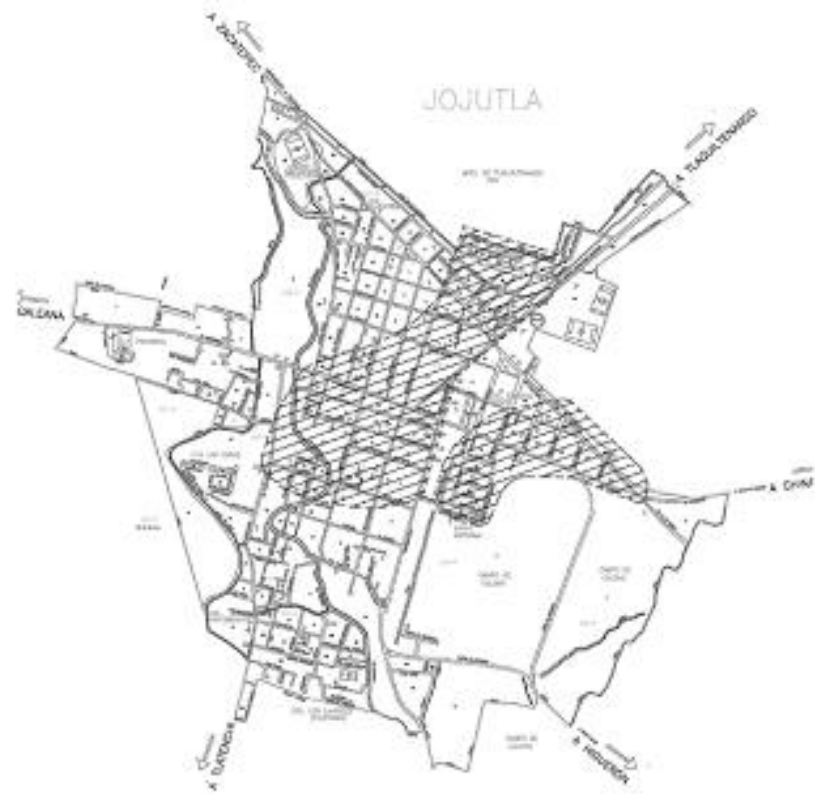

Figure 5. Seismic regionalisation of the 2017 Puebla earthquake in the town of Jojutla de Juárez, Morelos. Source: Jojutla Emergency Brigades (2017).
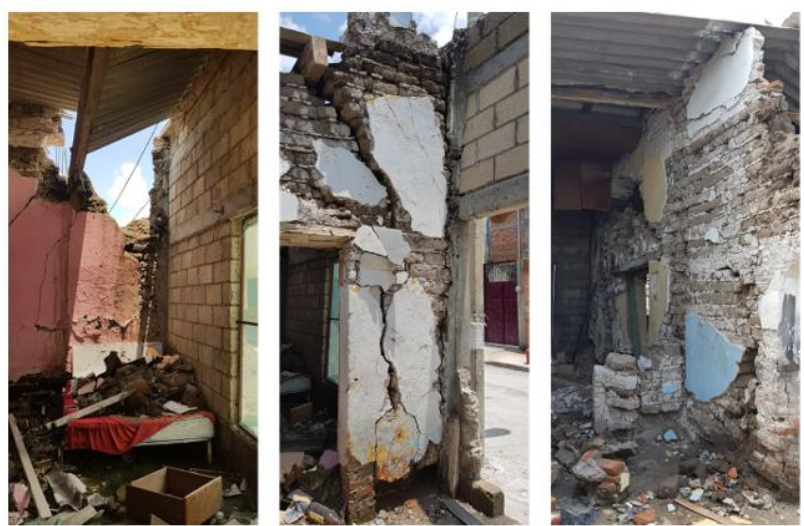

Figure 6. Damages in adobe buildings of Jojutla de Juárez. Photo: Adrià Sánchez Calvillo (2018). (C) SPOT Image Copyright 2020.

Notwithstanding the loss of the main monuments and the vernacular architecture, the organisations in charge decided to discredit the local architectural culture, calling adobe bricks as an unsafe material (Guerrero Baca, 2019). This turned into the abandonment of the traditional techniques and the reconstruction of the region with prefabricated concrete blocks and ceramic brick walls and roof structures with metal beams. Considering the risk situation of the earthen architecture in México (Guerrero Baca, 2007), this seismic event worsen the loss of adobe housing in the regions affected. However, this is not a local problem of Morelos, the other states damaged by the 2017 earthquakes have experienced similar problems, which correlate with the oblivion and abandonment of the local seismic culture previously mentioned. In certain cases, even if the buildings only present minor damages and an apparent good condition, families show a preference for demolishing their own buildings and rebuild with 
new materials and resources offered as compensation for the losses. This is one of the major difficulties the experts have to face when visiting communities, to convince them that modern materials also generate problems in the environment (Cornerstones Community Partnerships, 2006).

Other factors that contribute to the abandonment of the earthen architecture are the lotification or division of the land and the intervention and substitution of the traditional materials for modern ones (Azevedo Salomao, 2011). With the growth of the families and the partition of the old houses, the great thickness of the adobe walls became a problem because the owners need more space. This social reality causes new situations in the dwellings, which contribute to generate new problems. Many landlords begin to alterate the morphology of the buildings and build second or third levels to the original dwellings, normally with modern materials which are not compatible with the traditional ones. These modern materials also represent the progress, an indication of the social status in the community that is really hard to change in their mindset.

\section{METHODOLOGY}

\subsection{Materials used and preparation of the specimens}

In order to study the seismic disaster affectation on the adobe dwellings of Jojutla de Juárez, several samples were collected to be analysed in the laboratory. Considering the state of the municipality and its population, the sample collection responded to the criteria of taking the maximum amount of material possible before the demolition of the remaining houses. Shortly after the recollection of the specimens, the remaining earthen buildings and structures were demolished, with the consequent disappearance of the vernacular architecture of the town. There also were taken samples of soils of the region, in particular where the material is extracted and adobe bricks and ceramic bricks manufactured.

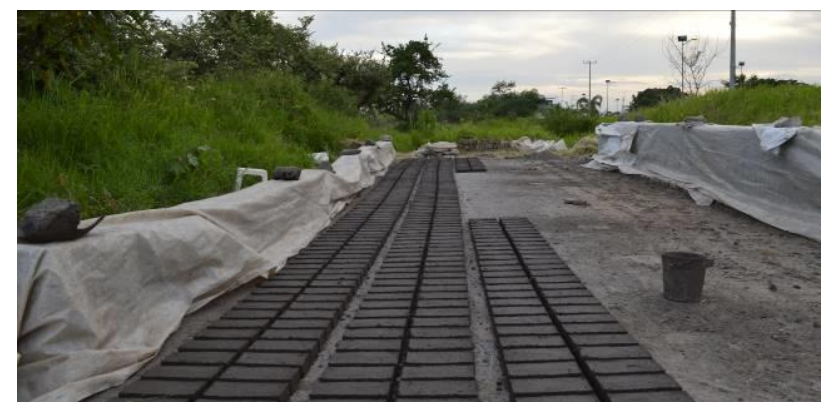

Figure 7. Manufacture area of the ceramic bricks of the region. Photo: Adrià Sánchez Calvillo (2018). C) SPOT Image Copyright 2020.

The research was focused on the material characterisation of the adobes and soils of the region for various reasons. First of all, the traditional buildings of the town collapsed or were very affected by the earthquake, with the following demolition by the users; as it was said before they did not trust earthen materials and perceived them as unsafe. This situation complicated the whole building analysis, therefore the main focus was the material, the adobe bricks, which are an essential factor of the traditional houses of México. The other reason was to perform analysis on damaged samples, to understand the behaviour of the construction materials after a natural disaster and compare them with 'healthy' ones (Alonso, Martínez, 2003). Earthen architecture has been analysed widely against seismic risks.

\subsection{Sieve analysis and USCS}

The samples of the quarries and the adobes were brought to the laboratory, where they were divided till achieve the dimensions required for the standards. The material was classified by the Unified Soil Classification System (USCS), repeating each trial at least three times. It also was possible to separate and calculate the fibre percentage, straw in the case of study, in each one of the adobes.
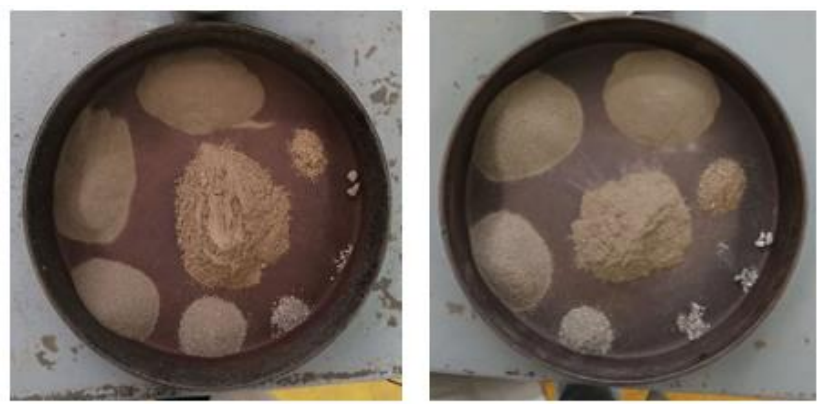

Figure 8. Breakdown and grain size of the adobe samples. Photo: David Preciado Villicaña (2019). c) SPOT Image Copyright 2020.

The USCS classification of the material shows relevant information. Samples M1 and M13 correspond to the natural clays from the quarries near Jojutla and are clays of high plasticity. The other samples, corresponding to the adobe blocks of the downtown are either clays of low plasticity or silts (Table 1); also the plasticity graphic shows how the healthy clays of the soil samples are in very different zone of the graphic than the adobe samples. (Figure 9) This demonstrates that the adobes contained other materials probably due to the attempt to stabilise them.

\begin{tabular}{ccc}
\hline Sample & & USCS Classification \\
\hline M1 & CH & Clay of high plasticity \\
\hline M2 & CL & Clay of low plasticity \\
\hline M3 & CL & Clay of low plasticity \\
\hline M4 & CL & Clay of low plasticity \\
\hline M5 & ML/OL & Silt (Mud) / Organic silt, light plasticity \\
\hline M6 & ML/OL & Silt (Mud) / Organic silt, light plasticity \\
\hline M12 & ML/OL & Silt (Mud) / Organic silt, light plasticity \\
\hline M13 & CH & Clay of high plasticity
\end{tabular}

Table 1. USCS Classification of the specimens.

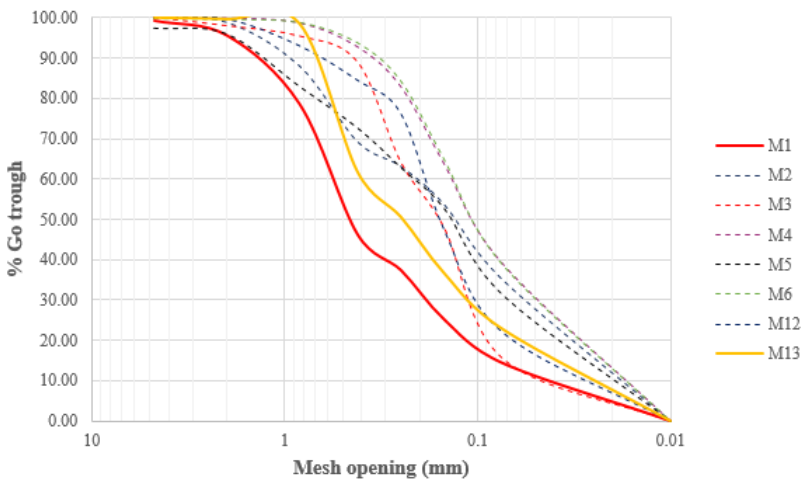

Figure 9. Granulometric curves of the adobes and soils. Continuous line: Natural soils, Discontinuous line: Adobes. 
The only type of fibre contained and found in the adobe bricks was straw, it was observed from the beginning that some of the samples did not have any significant amount of it, while others had considerable. The use of fibres in adobe masonry functions as a reinforcement or strategy to decrease the shrinkage (Yetgin et al., 2008; Sharma et al., 2015). The percentage of straw from the total weight was calculated. The adobes stabilised with straw presented values of percentage from weight with ranges of 0.2 $1.80 \%$.

As it has been said, some of the samples did not have any amount of straw or really low percentage of it, situation which contributed to the lower mechanical values obtained with the compression test; besides, some of the adobes had considerable amounts of straw, nevertheless the placement and direction inside the brick was chaotic, unlike the typical vernacular examples where the straw is strategically positioned to avoid shrinkage. Since the recollection of the specimens, it was observed that the adobes were significantly different, from size, texture, color, composition and form; with the sieve analysis it was possible to corroborate the assumption that vernacular construction was forgotten in Jojutla de Juarez.

\subsection{Colorimetry}

Natural clays of the quarries near Jojutla de Juarez were materials are extracted, were compared by colorimetry tests with the traditional adobe samples which were collected in the town after the earthquake. The results of the colorimetry tests allow us to understand how the natural and artificial aggregates of the adobe bricks change the natural colour of the clay.

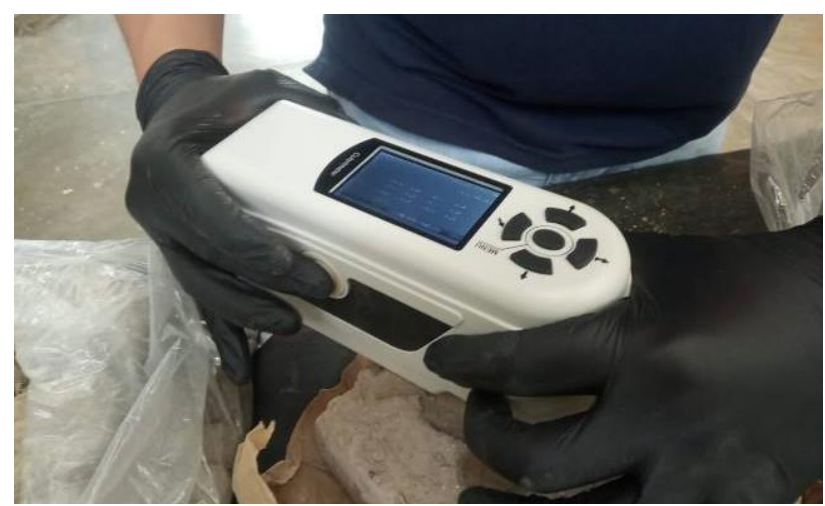

Figure 10. Use of the colorimetry equipment in an adobe sample. Photo: David Preciado Villicaña (2019). (C) SPOT Image Copyright 2020.

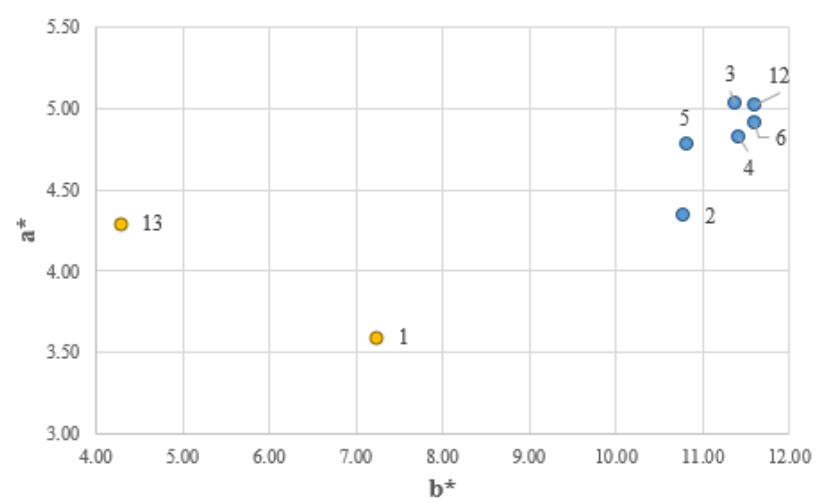

Figure 11. Colorimetric values of the samples. Yellow: Natural clays, Blue: Modified adobes.
This method also can be compared with other laboratory tests resulting in complementary studies, particularly the modification and stabilization of clays with different additives, correlating the change in colour with other properties. The colorimetry equipment illuminates the surface of the specimens and reads the scattered light. Before the use, the equipment needs to be calibrated with a white reference (Martínez, et. al., 2018), then several values are taken for each sample and an average value is calculated. The results are shown in a coordinate graphic with two axis which enables to identify the colour variations between different samples (Figure 11).

The results of the colorimetry show a separation between the healthy clays from the quarries and the samples of adobes from the downtown. This change of the colour is produced by the addition of other elements to the mixture, excluding the natural fibres, like straw, which not contribute to the variation. There were found remainders of lime with the microscopy tests; lime is one of the main stabilisers in earthen architecture and has been combined with clay for centuries (Villaseñor Alonso, Barba Pingarrón, 2012; Navarro et al., 2019). The presence of stabiliser elements also explains the transformations of the soils, clays of high plasticity, to the low plasticity materials of the adobes (Table 1)

\subsection{Compressive strength}

One of the main properties to analyse was the compressive strength, in general adobe blocks present lower compression resistances, but with reinforcement and stabilisation strategies these values can increase. Because of the unusual state of the adobes of Jojutla de Juarez, collected after an earthquake, there was necessary to prepare the samples to execute the trial. The samples were carved till obtain the required dimensions, and later cap with sulphur, due to the irregularities presented in their morphology. Once prepared, they were introduced in the Universal Test Machine to test their ultimate resistance to compressive strength. Not all the samples could be used, due to the mentioned irregularities and the unstable state of the fragments.

The results of the Compression strength test were not encouraging, with resistance values between $5-13 \mathrm{Kgf} / \mathrm{cm}^{2}$, being the average of $7.26 \mathrm{Kgf} / \mathrm{cm}^{2}$, really low compared to other studies of the adobes of Morelos, which can achieve $16 \mathrm{Kgf} / \mathrm{cm}^{2}$. (Guerrero Baca, 2019) Other Mexican studies also characterised the compressive resistance of this material, obtaining major values in all the cases (Arroyo Matus et al., 2013; Cruz Farrera, 2018; Ordaz Zapata, 2019).

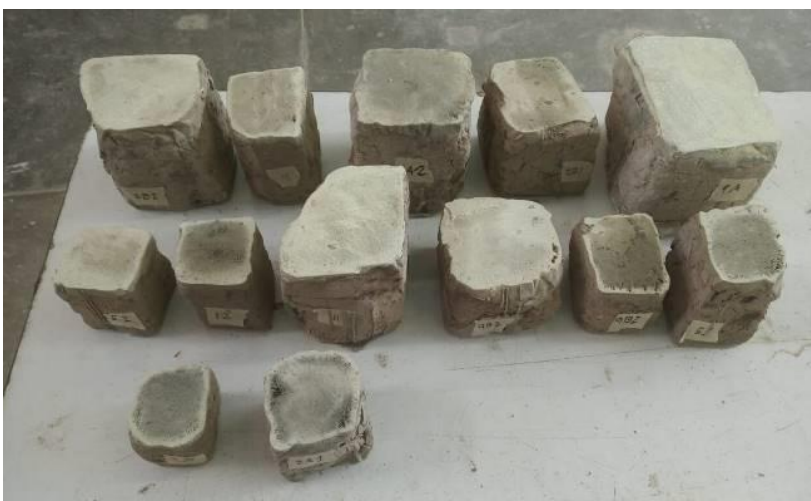

Figure 12. Adobe samples prepared for the compression test. Photo: Adrià Sánchez Calvillo (2019).

(c) SPOT Image Copyright 2020. 
With other mechanical characterisation method, the point-load test, it was possible to analyse the resistance of the adobe fragments which could not be submitted to the compressive trial. The point-load test allows determining the mechanical resistance of non-carved samples of several types of masonries and rocks (ASTM D5731-05, 2007). The methodology followed the standards and previous research works performed in the materials laboratory (ASTM ID5731-16, 2016; Navarrete Seras et al., 2014; Navarrete Seras et al., 2017). The values obtained were more variable with an extended range, being the average of all the adobes $5.30 \mathrm{Kgf} / \mathrm{cm}^{2}$, lower than the compression strength results. The use of the point-load test was really suitable because of the irregular condition of the adobe samples, being the analysis posterior to the compressive strength test, therefore the samples were altered.

\section{CONCLUSIONS}

The high seismic vulnerability of the adobe buildings of Jojutla de Juárez responds to several causes, being multifactorial. Some of them have been explained with the field trips to the locality and the observed vulnerability of the structures. Some of the deficiencies found in Jojutla were: wrong location of the openings like doors and windows, the lack of horizontal reinforcements, walls with insufficient thickness, the bad quality of the adobes, the lack of diaphragm between the walls and the roof structure, the use of non-compatible materials or the irregularities in the morphology and height of the buildings. The combination of these resulted into the poor performance of the structures when the earthquake struck. Nevertheless, these buildings have been demolished and the only current remaining are the adobe samples which were collected and transported to the laboratory.

On the other hand, the characterisation of the material allowed obtaining the mechanical properties of the blocks. The values obtained for the compression strength are lower than values from other researches which characterise similar cases of traditional adobe houses in México (Guerrero Baca, 2019; Arroyo Matus et al., 2013; Cruz Farrera, 2018; Ordaz Zapata, 2019). These indicators show that the adobe blocks of Jojutla presented a poor performance and manufacture. This poor performance of the blocks responds to various factors: the absence of fibres or the wrong placement inside the block, the election of the soils and composition of the adobes, derived from the oblivion of the construction traditions. Nevertheless, this low values did not justify for itself the bad seismic behaviour of the dwellings, which were very vulnerable due to multiple factors like the lack of reinforcements and confinement of the structures. The use of point-load was also interesting, as this method enables to do research with damaged and irregular samples, not only complete blocks; it can be a useful option for the study of construction materials after natural disasters like earthquakes.

From the other analysis, it can be assessed that the adobes of Jojutla were stabilised with other materials aggregated to the soil and fibres. The colorimetry test shows a significant variation between the natural clays and the adobes; it is interesting that the variation between the adobe bricks is minimum, consequently the constructors followed a common pattern. The sieve analysis confirms the variations in the standard values obtained from the natural clays, as these went from clays of high plasticity to clays of low plasticity and silts. Other of the elements found in the adobes was straw, but this was not present in all the samples, therefore it can be deducted that at some point in the recent history the traditional manufacture of the adobe bricks and vernacular houses was forgotten. The stabilisation, however, did not help to raise the compressive strength of the specimens, as the results obtained were really low.

While seismic vulnerability has been widely researched for monumental and vernacular architecture including adobe buildings with the creation of various vulnerability assessment methodologies (Díaz Fuentes, 2017; Brando et. al., 2019; Ortega et al., 2020), it is very complicated to analyse study cases where the materials and buildings have been lost or demolished. This research work attempts to be a first approach to the study of affected regions or cases where damages have been especially severe and complete methodologies cannot be followed. In the case of Jojutla de Juarez, the whole analysis of the buildings was impossible to achieve, due to the disappearance of the same, therefore the material remaining was the object of study. The research done may be complemented with other analysis, not only referred to the material but the vulnerability of the population, as it is expected to be extended with data of the lost buildings derived from the historical documentary analysis and geographic information systems.

\section{ACKNOWLEDGEMENTS}

The authors acknowledge the Materials Laboratory 'Ing. Luis Silva Ruelas' of the Faculty of Civil Engineering of the UMSNH for the equipment support, the Postgraduation coordination of the Faculty of Architecture of the UMSNH, the economic support given by CONACYT, and the technical support of B.C.E. D. Preciado Villicaña and M. Ruiz Mendoza.

\section{REFERENCES}

Alonso E., Martinez L., 2003: The role of environmental sulfur on defradation of ignimbrites of the Cathedral in Morelia, Mexico. Building and Environment, 38, 861-867. doi.org/10.1016/S0360-1323(03)00023-4

Arroyo, R., Sánchez. S., Catalán. P., 2013: Caracterización experimental de las propiedades mecánicas de la mampostería de adobe del sur de México. Ingeniería, 17(3), 167-177.

ASTM International, 2016. ASTM D5731-16, Standard Test Method for Determination of the Point Load Strength Index of Rock and Application to Rock Strength Classifications. West Conshohocken, PA. doi:10.1520/D5731-16.

ASTM Standards, 2007. ASTM D5731 - 05 Standard Test Method for Determination of the Point Load Strength Index of Rock.https://www.astm.org/DATABASE.CART/HISTORICAL /D5731-05.htm.

Azevedo, E. M., 2011: Habitar y habitabilidad. In Salazar G., Azevedo E. M., Ettinger C. R., Paredes B., Torres L. A., Lecturas del Espacio Habitable. San Luis Potosí, S.L.P., México: Universidad Autónoma de San Luis Potosí, 57-78.

Blond, M., Vargas, J., Tarque, N., Iwaki C., 2011: Construcción sismorresistente en tierra: la gran experiencia contemporánea de la Pontificia Universidad Católica del Perú. Informes de la Construcción, 63(523), 41-50. doi:http://dx.doi.org/10.3989/ic. 
Brando,, G., Cocco G., Mazzanti, C., Peruch, M., Spacone, E., Alfaro, C., ... Tarque, N., 2019: Structural Survey and Empirical Seismic Vulnerability Assessment of Dwellings in the Historical Centre of Cusco, Peru. International Journal of Architectural Heritage. doi:10.1080/15583058.2019.1685022.

Chardon, A. C., 2008: Amenaza, vulnerabilidad y sociedades urbanas una visión desde la dimensión institucional. Gestión y ambiente, 11(2), 123-135.

Consejería Jurídica del Poder Ejecutivo del Estado de Morelos, 2016: Plan Municipal de Desarrollo 2016-2018, del Ayuntamiento de Jojutla, Morelos. Dirección General de Legislación, Subdirección de Jurismática. Jojutla de Juárez, México: Ayuntamiento Constitucional de Jojutla, Morelos.

Cornerstones Community Partnerships, 2006: Adobe conservation: a preservation handbook. Santa Fe, New Mexico: Sunstone Press.

Cruz, F. J., 2018: Propuesta de uso de tecnologías sismorresistente de adobe para una vivienda progresiva en Cuauhtémoc, municipio de Villaflores, Chiapas. Tuxtla Gutiérrez, México: Universidad Autónoma de Chiapas.

del Campo, R. M., Ochoa G. H., Álvarez F., 2018: Estudio Geotécnico de la Colonia Emiliano Zapata, Jojutla, Morelos, tras los daños de los Sismos del 19 de septiembre de 2017. ITESO, Universidad Jesuita de Guadalajara, Departamento de Hábitat y Desarrollo Urbano.

Díaz, D. A., 2017: Un método simplificado para evaluar el riesgo sísmico y priorizar la atención de los bienes culturales inmuebles: el caso de Chile. Intervención: Revista de Restauración, Conservación y Museología, 8(15), 46-62.

Díaz,, D., Baquedano P. A., D'Amato, M., Laterza, M., 2019: Preliminary Seismic Damage Assessment of Mexican Churches after. International Journal of Architectural Heritage. doi:10.1080/15583058.2019.1628323

Ferrigni, F., 2015: Vernacular architecture: A paradigm of the local seismic culture. In Correia M., Lourenço P. B., Varum H. (Edits.), Seismic Retrofitting: Learning from Vernacular Architecture. London, UK: Taylor \& Francis Group.

Guerrero, L. F., 2007: La pérdida de la arquitectura de adobe en México. In ICOMOS, Petzet M., Ziesemer J. (Edits.), ICOMOS world report 2006/2007 on monuments and sites in danger 112114. Altenburg, Alemania: ICOMOS.

Guerrero, L. F., 2019: Comportamiento sísmico de viviendas tradicionales de adobe, situadas en las faldas del volcán Popocatépetl, México. Gremium, 6(11), 105-118.

Guerrero, L. F., Vargas, J., 2015: Local seismic culture in Latin America. In Correia M., Lourenço P. B., Varum H. (Edits.), Seismic Retrofitting: Learning from Vernacular Architecture. London, UK: Taylor \& Francis Group.

Guerrero, L. F., Meraz, L., Soria, F. J., 2014: Cualidades sismorresistentes de la vivienda de adobe en las faldas del volcán Popocatépetl. In Guerrero L. F., Reutilización del patrimonio edificado en adobe, 194-215. México D.F.: Casa Abierta al Tiempo: Universidad Autónoma Metropolitana.
Guerrero, L. F., 1996: La vivienda tradicional en los Valles Altos de Morelos. Una aproximación tipológica. Estudios de tipología arquitectónica 1996. México: U.A.M. Azcapotzalco.

Jorquera, N., 2014: Culturas sísmicas: Estrategias vernaculares de sismorresistencia del patrimonio arquitectónico chileno. Arqutiecturas del Sur, XXXII(46), 18-29.

Martínez, W., Torres-Acosta, A. A., Alonso-Guzmán, E. M., Chávez, H. L., Lara, C., Bedolla, A., . . Ruvalcaba, J. L., 2018: Colorimetry of clays modified with mineral and organic additives. Revista ALCONPAT, 8(2), 163-177.

Meli, R., 2018: La ingeniería civil ante los efectos de los sismos de 2017 en los edificios patrimoniales (el equilibrio entre la autenticidad y la seguridad). In S. d. Cultura, Sismos y patrimonio cultural. Testimonios, enseñanza y desafios, 2017 y 2018, 62-81. Ciudad de México: Dirección General de Publicaciones de la Secretaría de Cultura.

Navarrete, M. A., Chávez, H. L., Martínez, W., Alonso, E. M., Arreola, M., 2017: Bank Material Study for the Restoration of Historical Monuments in Michoacán, México. Materials Science Forum, 902, 47-51.

doi:doi:10.4028/www.scientific.net/MSF.902.47

Navarrete, M., Mártinez, W., Alonso, E. M., Arteaga, J., Chávez, H. L., Lara, C., ... Díaz, N., 2014: Mathematical models applied to the physicalmechanical mechanical characterization of stone materials bank Huiramba, México. In Esquivel K., Elizalde E., Rodríguez J. A. (Ed.), X Congreso Internacional de Ingeniería. Engineering and its applications Vol. 1. 252-256. Querétaro: Universidad Autónoma de Querétaro.

Navarro, E. G., Sánchez, A., Bedolla, J. A., Alonso, E. M., 2019: La cal de alta pureza, alternativa ecológica en los acabados de las construcciones. In. Alonso F. A., Olguín F. J. (Ed.), XV Congreso Latinoamericano de Patología de Construcción y XVII Congreso de Control de Calidad en la Construcción. CONPAT 2019, Vol. 2, PATOLOGÍA. Tuxtla Gutiérrez, Chiapas. doi:https://doi.org/10.21041/CONPAT2019/V2PAT130

Niglio, O., 2015: El valor del patrimonio cultural entre extremo Oriente y extremo Occidente. Roma: ARACNE Editrice.

Ordaz, F. A., 2019: Estudio de las características mecánicas y térmicas del adobe, para su revalorización en la construcción de vivienda, en la ciudad de Torreón Coahuila, México. Torreón, México: Universidad Autónoma de Coahuila.

Ortega, J., Vasconcelos, G., Rodrigues, H., Correia, M., 2020: Seismic Vulnerability and Loss Assessment of Vila Real de Santo António, Portugal: Application of a Novel Method. International Journal of Architectural Heritage. doi:10.1080/15583058.2019.1709915

Servicio Sismológico Nacional, 2017: Reporte especial. Sismo de Tehuantepec (2017-09-07 23:49 Mw 8.2). UNAM, Grupo de trabajo del Servicio Sismológico Nacional. México: Universidad Nacional Autónoma de México.

Servicio Sismológico Nacional, 2017: Reporte especial. Sismo del día 19 de Septiembre de 2017, Puebla-Morelos (M 7.1). UNAM, Grupo de trabajo del Servicio Sismológico Nacional. México: Universidad Nacional Autónoma de México. 
The International Archives of the Photogrammetry, Remote Sensing and Spatial Information Sciences, Volume XLIV-M-1-2020, 2020

HERITAGE2020 (3DPast | RISK-Terra) International Conference, 9-12 September 2020, Valencia, Spain

Servicio Sismológico Nacional, 2017: Servicio Sismológico Nacional | UNAM, México.

http://www2.ssn.unam.mx:8080/mapas-de-intensidades/

Sharma, V., Vinayak, H. K., Marwaha, B. M., 2015: Enhancing sustainability of rural adobe houses of hills by addition of vernacular fiber reinforcement. International Journal of Sustainable Built Environment(4), 348-358.

Villaseñor I., Barba L., 2012: Los orígenes tecnológicos de la cal. Cuiculco, 55, 11-41.

Yamín L. E., Phillips C., Reyes J. C., Ruiz D., 2007: Estudios de vulnerabilidad sísmica, rehabilitación y refuerzo de casas en adobe y tapia pisada. Apuntes: Revista de estudios sobre patrimonio cultural, 20(2), 286-303.

Yetgin, Ş., Çavdar, Ö., Çavdar, A., 2008: The effects of the fiber contents on the mechanic properties of the adobes. Construction and Building Materials(22), 222-227. 